\title{
Developing English Vocabulary Application for The Mentally-Retarded Students at SLB Arya Satya Hati
}

\author{
Asrita Annisa ${ }^{1}$, Barotun Mabaroh', Rasyidah Nur Aisyah ${ }^{3}$ \\ English Education Study Program, Faculty of Pedagogy and Psychology, University of PGRI \\ Wiranegara (UNIWARA) Pasuruan, East Java, Indonesia \\ E-Mail: asrita.sita@gmail.com
}

\begin{abstract}
The aim of this study was to develop the application of English Vocabulary Application based on the desktop version to assist the mentally-retarded students in learning English vocabulary. This research used Research and Development (R\&D) with ADDIE models. This research involved 5 seventh-grader of mentally-retarded students and 3 teachers who teach mentally-retarded students from SLB Arya Satya Hati. The researcher used three instruments for this research: Interview,Questionnaire, and Documentation. The data were analyzed by using Arikunto's theory (2010) and percentage index (\%). The researcher carried out the dissemination by uploading the video on how to operate the English Vocabulary Application on Youtube due to the COVID-19 pandemic. From the validation results, it showed that English Vocabulary Application was feasible to be used as a learning media in assisting the mentally-retarded students with $100 \%$ materials validation results and 95\% programming validation results. Based on the application try-out, 4 MR students could guess more than 10 words of 20 words and 1 MR student guessed 8 words of 20 words. Based on this research, the English Vocabulary Application could be used in teaching- learning vocabulary for mentally-retarded students through ICT. This application could be used as one ICT learning media and the other researcher could develop this application with the newest features.
\end{abstract}

Keywords: English Vocabulary Application, Mentally-Retarded students, teaching vocabulary

\section{INTRODUCTION}

Learning English is important because English is a global language which means in this world, more than 1.5 billion people speak in English (stgeorges.co.uk). In Indonesia, learning English is an opportunity for every students and English becomes one of compulsory subjects (Colon, 2017). In addition, Depdiknas UU no. 20 Year 2003 article 33 declares that English language can be used as a language of instruction in order to support the ability of speaks foreign language. Learning English is always related to learning vocabulary. Vocabulary is one of the knowledge areas in language and play a great role for learners in acquiring a language (Pintrich, 2013).

In this era, using technologies are required in learning process. Using ICT or E - learning media is commonly occur in public school or private school as learning tools. But it will be different with special need school or inclusive school especially mentally-retarded students(Hinchcliffe, 2014). According to Ministry of Education DOI: https://doi.org/10.25217/jed.v1i01.1500 
Regulation Number 70 year 2009 about special needs education for special needs student state that students who have physical abnormalities, emotional, mental, social, and / or have potential special intelligence and / or talent needs to get educational services that match with their needs and rights.

According to (National Reading Panel, 2000), Mental Retardation is children with developmental learning problem caused by the developmental barriers of intelligence, mental, emotional, social, and physics. It is commonly accepted that mentallyretarded (MR) students experience more difficulties in learning a foreign language when compared to other students. Using ICT for MR students rarely used because most of them cannot understand well about the materials. For this reason, the researcher intended to develop an English Vocabulary Application which matches to the MR students' condition (Dawamuddin, 2021).

The researcher chose Sekolah Luar Biasa (SLB) Arya Satya Hati Pasuruan. This is one of the special needs school in the city of Pasuruan that accept MR students.

As the need analysis, the researcher here interviewed with three teachers and did some pre- test to two mentally-retarded students. The results from the interview are 1) the teachers used conventional methods such as drilling in learning English vocabulary, 2) teaching vocabulary was so challenging since the mentally-retarded students are only able to memorize a few vocabulary and it must be repeated within a week. 3). the teachers never used ICT or E-learning media to teach mentally-retarded students(Amankulova \& Seisembieva, 2011). The result from pre-test was the students was able to memorize only 2-3 words from 7 words given by the researcher. From the need analysis, the researcher believed that it is needed to develop an English vocabulary application for teaching vocabulary to the mentally-retarded students. Through the application, it would vary teaching vocabulary methods and motivate the students(Uchihara \& Clenton, 2020).

Developing teaching vocabulary media for the MR students using C\# program can be one option. It is a program developed by Microsoft to build website, desktop application, or mobile application. The concept of the application is to combine the vocabulary, audio, picture, and game in one frame in order to simplify learning vocabulary. This application only run in desktop version or computer version with Windows 10 Pro as operating system in computer. There is also materials and games which can be played by the students. This application divided into two section; materials and practice. Before using practice, the teacher should teach the vocabulary from materials section (Ndraha \& Kurniawan, 2019). The contain of materials section and practice sections are same. 
Based on the background of the study, the research problem is How to develop English Vocabulary Application for the mentally-retarded students?. The objectives of this research is to develop English Vocabulary Application for Mentally-Retarded Students with C\# program.

\section{METHOD}

In this research, the researcher chose Research and Development as a research method. In this research, the researcher develops the English Vocabulary Application using ADDIE models. According to Dick and Carey (1996), ADDIE models stand up for five steps, they are 1). Analyzing; 2). Designing; 3). Development; 4). Implementation; and 5). Evaluation(Hall \& Lerner, 2010).

From the analyze phase, the researcher took a pre-test from two MR students and interview with three teachers. From the design phase, there were eighty vocabularies divided into twenty chapters in the application. From the development phase, the development is carried out by realizing the concept of learning vocabulary that has been made. The researcher assisted by a programmer to make an English Vocabulary Application. From the implementation phase, the researcher took the first trial for five seventh-grader of MR students of SLB Arya Satya Hati. The researcher did not take faceto-face dissemination due to the COVID-19 pandemic. The researcher took video recording on how to run the English Vocabulary Application and upload it on YouTube. From the evaluation phase, the researcher took the summative evaluation and the formative evaluation. In summative evaluation, the researcher took the data from try-out the product at small group. The formative evaluation from experts' validation has intended to increase the quality of the application.

The researcher chose a small group for the design of try-out. The researcher chooses five seventh-grader of MR students at SLB Arya Satya Hati. The field trial for the whole class cannot be carried out due to the COVID-19 pandemic. At the end of teaching-learning vocabulary, the students answered the questionnaire about the quality of the application.

The researcher analyzed the result of the validation and the questionnaire by using (Tanzeh \& Arikunto, 2004) and categorized the result of the validation by using (Istiyani et al., 2017). The formula and the category of percentage are shown as follow:

$\mathrm{P}=$ the percentage of the responds

$$
P=\stackrel{F}{ }=100 \%
$$

$\mathrm{F}=$ the frequency of the validator's

DOI: https://doi.org/10.25217/jed.v1i01.1500 
answer $\mathrm{N}=$ the total of maximum point

Table 1 The Category of Percentage by Alifah (2013)

\begin{tabular}{|c|c|}
\hline Percentage & Category \\
\hline $81 \%<$ score $<100 \%$ & $\begin{array}{c}\text { Very } \\
\text { Good }\end{array}$ \\
\hline $61 \%<$ score $<80 \%$ & Good \\
\hline $41 \%<$ score $<60 \%$ & Fair \\
\hline $21 \%<$ score $<40 \%$ & Poor \\
\hline $0 \%<$ score $<20 \%$ & Very Poor \\
\hline
\end{tabular}

\section{Need Analysis}

\section{DISCUSSION AND RESULT}

The researcher gathered the data of need analysis from the interview with teachers and conducted the pre-test for MR students. Based on the interview results, the researcher concluded that the teachers use conventional methods such as drilling and using flashcards to teach vocabulary. The obstacles during teaching-learning vocabulary commonly occurred one of them is not able to memorize the vocabulary in a long time. Therefore, teachers must repeat the materials frequently. Some teachers at SLB Arya Satya Hati never used ICT in teaching vocabulary. Based on the pre-test result, the student one was able to remember three words out of seven words and the student two was able to remember two words out of seven words.

\section{Experts' Validation}

The researcher conducted validation to some experts who have good experience related to this product. There were four expert validators to test the validity of this product. The researcher chose two materials experts as the material validators and two programming experts as the programming validators.

The first material validator came from Ana Ahsana El-Sulukiyyah, S.Pd, M.Pd as Learning materials validator 1 . The result of learning materials validation was $100 \%$. The learning material validator 1 gave suggestion for the audio to pronounce the vocabulary. The validator 1 suggested revising the audio since the audio was less audible.

The second material validator data came from Suliswati, S.Pd as Learning materials validator 2 . The result of learning materials validation was $100 \%$. The learning material validator 2 did not give suggestion related to the application.

The first programming validator data came from Tedjo Baskoro as Programming

DOI: $\underline{\text { https://doi.org/10.25217/jed.v1i01.1500 }}$ 
the validator 1 . The result of programming validation was $93.333 \%$. The programming validator 1 gave suggestions for the scoring system in the application. The validator 1 suggested revising the scoring system since it was not working properly.

The second programming validator data came from Rendy Dwi Reksiyano as Programming Validator 2. The result of programming validation was $96.667 \%$. The programming validator 2 gave suggestions for the color composition in the application. The validator 2 suggested revising the color composition since the theme of background application was only dark mode and some pictures in the application had dark colors.

\section{Small Group Try-Out}

The researcher gathered the data of small group try-out from application try-out and questionnaire for MR students. The data from the application tryout was taken by conducting the application to a small group. The small group consisted of five MR students. The researcher conducted a questionnaire for MR students after finishing the teaching-learning vocabulary through English Vocabulary Application.

Based on the result of application try-out, student one could guess 11 right words of 20 words, student two could guess 10 right words of 20 words, student three could guess 20 words of 20 words, student 4 could guess 8 right words of 20 words, and student five could guess 10 words of 20 words.

Based on the questionnaire results, the learning strategy by using English Vocabulary Application has been appropriate. The pictures and audio in the English Vocabulary Application has been appropriate. The English Vocabulary Application is easy to use. The display on the English Vocabulary Application has been well. The use of the application can help MR students to learn English Vocabulary. The English Vocabulary Application also can attract MR student's interest and attention. The learning process by using English Vocabulary Application can encourage MR students to access technology properly.

\section{ANALYSIS}

\section{Need Analysis}

From the interview with three teachers, it was revealed that the teacher used the drilling method and using flashcards to teach vocabulary. The use of flashcards was intended to make the students interested in the materials and did not get bored. In line with (Habibi, 2017), MR students tended to be bored and having low participation in English class. The teachers also faced the difficulties in teaching vocabulary such as the materials should be repeated frequently. The teachers should repeat the vocabulary until the MR students could memorize it. The teachers also revealed that they never use 
ICT learning to teach vocabulary for MR students.

From the pre-test for MR students, it revealed that vocabulary mastery for two MR students were still lacking. The S1 gained three words out of seven words. While the S2 gained two words out of seven words. This could happen because the MR students did not understand well the vocabulary and had difficulty pronouncing, or the students got bored and forgot the vocabulary they had taught (Anggraeni, D., Marhum, M., \& and Mertosono, 2016).

\section{Experts' Validation}

From both learning materials validator, the average of the percentage result was $100 \%$. Based on the technique of data analysis by (Alifah, 2013), the category of average percentage from both learning materials validators was very good. Thus, the researcher could conclude that the learning materials for English Vocabulary Application was valid and it could be implemented in the class.

From both programming validators, the average of the percentage result was $95 \%$. Based on the technique of data analysis by (Alifah, 2013), the category of average percentage from both programming validators was very good. Thus, the researcher could conclude that the application program was valid and it could be implemented in the class.

The experts also gave suggestions related to this application. The suggestion from the experts is used to revise the application. Some suggestions are changing the audio, changing the system score into a game system score, and changing the color composition by adding the light mode for the theme.

\section{Small Group Try-Out}

Based on the data from application try-out, it was revealed that the students understand the materials. It is proven by $3 \mathrm{MR}$ students from $5 \mathrm{MR}$ students who can achieve more than 10 words out of 20 words. In line with Sari (2020), the use of application Vorily could increase the students' score and the students' interest. Furthermore, 4 MR students prefer to study the "Food" chapter. 3 MR students chose "Our body, Family, and Animals" chapter. 2 MR students chose the "Beverages" chapter.

Based on the data from the questionnaire for MR students, it revealed that using English Vocabulary Application has been appropriate. The pictures, the audio, and the display in the application have been appropriate. According to Wijayanti and Padmaningsih (2014), the used of pictures in learning vocabulary could construct the students' visualization power to determine the words. Furthermore, English Vocabulary Application is easy to be used. 
However, the use of English Vocabulary Application still cannot help MR students to learn English vocabulary maximally. Yet the use of English Vocabulary Application can attract the students' interest and attention. By using English Vocabulary Application can help the students to encourage themselves for using technology properly.

\section{FINAL PRODUCT}

Based on the result of the product in this research, the product was application English Vocabulary Application using C\# programming for the seventh-grader of MR students at SLB Arya Satya Hati Kota Pasuruan. This learning media is used for teaching-learning English vocabulary. This product provides some menu to help students and teachers in using this application.

To run this application, the computer or laptop should have Windows 10 Pro as the computer operating system. After that, the users install the application by following the steps that have been provided. The user will go to the welcome screen. After entering the main menu page, the users will get a pearl-of-wisdom. The main menu page for the material section and the practice section is the same. For the practice section, there is a score box in the upper right corner of the main menu page. There are also messages for preventing COVID-19.

\section{The Strength}

This application consists of a combination of the pictures, the audio, and the games. The students can learn English vocabulary while playing games in the practice section. The students can also learn how to pronounce the word by listening to the audio on each word. Furthermore, this application can be applied not only for MR students but also for other students or young learners can learn English vocabulary through English Vocabulary Application.

There is a manual book for operating English Vocabulary Application in PDF form. This application is easy to be installed and it does not require a long time to install. The memory capacity of this application also small, it requires $12 \mathrm{MB}$ for the material section and $67 \mathrm{MB}$ for the practice section.

\section{The Weakness}

This application requires Windows 10 Pro as an operating system and only runs in the desktop version. Thus, English Vocabulary Application cannot run if the computer operating system is below Windows 10 Pro. 


\section{Conclusion}

\section{CONCLUSION AND SUGGESTION}

The development of the English Vocabulary Application is the first development of learning media based on ICT in SLB Arya Satya Hati. The English Vocabulary Application can be used for individual learning or small group since this application is easy to use. This application contains the materials section and the practices section. The purpose of this application is to teach vocabulary through ICT and encourage MR students to access the technology properly. Moreover, This application has low memory and it did not consume the hard disk space. Furthermore, the installation of this application is easy to be done. There is a manual book for running the English Vocabulary Application. This application can be used not for only the MR students but the young learners can learn the English vocabulary through this application. Yet, this application only runs on the computer with Windows 10 Pro as the operating system.

\section{Suggestion}

The English Vocabulary Application can be used by the teachers and the students especially MR students as one ICT learning media in teaching-learning English vocabulary. The teachers can also combine this application with other methods in order for increasing the student's interestand gain their attention.

The other researcher who has an interest in research and development of ICT learning media can improve the quality of this application by developing the newest features. The other researcher can develop the English Vocabulary Application in the mobile version since this application only runs on the desktop version.

\section{REFERENCES}

Alifah, S. (2013). Pengembangan Media Pembelajaran Fisika Berbasis Multimedia pada Pokok Bahasan Kalor untuk Siswa SMP kelas VII (Thesis). Semarang: IKIP PGRI Semarang Program Studi Pendidikan Fisika.

Amankulova, Z. I., \& Seisembieva, S. K. (2011). Teaching English as a foreign language. Analele Universitatii Din Craiova, Seria Filozofie. https://doi.org/10.2307/811234

Anggraeni, D., Marhum, M., \& and Mertosono, S. R. (2016). Teaching English Vocabulary to Mentally-Retarded Students of SLB Negeri 2 Palu Through Make-A-Match Technique. Bahasantodea, .

Colon, G. (2017). PALS for ELLS: Friend or foe? Effects of peer-assisted learning strategies on reading skills of English language learners with and without disabilities. Dissertation Abstracts International Section A: Humanities and Social Sciences, 77(12-A(E)).

Dawamuddin, Y. (2021). THE EFFECTIVENESS OF TEACHING VOCABULARY BY USING

DOI: https://doi.org/10.25217/jed.v1i01.1500 
PICTURE MEDIA TOWARD STUDENTS' SPEAKING ABILITY AT EIGHTH GRADE STUDENTS OF SMP IT AL ASROR SEKAMPUNG. Journal of English Development. https://doi.org/10.25217/jed.v1i01.1424

Habibi, N. (2017). The Use of Flashcards in Improving Vocabulary Mastery of Students with Disability. INKLUSI: Journal of Disability Studies, 4(2), 197-216. https://doi.org/doi:DOI: 10.14421/ijds.040203

Hall, B. H., \& Lerner, J. (2010). The financing of R\&D and innovation. In Handbook of the Economics of Innovation. https://doi.org/10.1016/S0169-7218(10)01014-2

Hinchcliffe, V. (2014). English. In Enabling Access: Effective Teaching and Learning for Pupils with Learning Difficulties. https://doi.org/10.4324/9781315067780-9

Istiyani, D., Zamroni, Z., \& Arikunto, S. (2017). A model of madrasa ibtidaiya quality evaluation. Research and Evaluation in Education, 3(1). https://doi.org/10.21831/reid.v3i1.13902

National Reading Panel. (2000). Teaching children to read: An evidence-based assessment of the scientific research literature on reading and its implications for reading instruction. $\mathrm{NIH}$ Publication No. 00-4769.

Ndraha, V. E., \& Kurniawan, M. (2019). Playing "CABE" (Searching and Whispering) to Increase Children's English Vocabulary. JPUD - Jurnal Pendidikan Usia Dini, 13(1), 143-157. https://doi.org/10.21009/10.21009/jpud.131.11

Pintrich, P. R. (2013). Educational psychologist. In Educational Psychologist. https://doi.org/10.4324/9781315046372

Tanzeh, A., \& Arikunto, S. (2004). Sugiyono, Metode Penelitian Pendidikan Pendekatan Kuantitatif, Kualitatif, dan R\&D, (Bandung: Alfabeta, 2010). Metode Penelitian.

Uchihara, T., \& Clenton, J. (2020). Investigating the role of vocabulary size in second language speaking ability. Language Teaching Research, 24(4).

https://doi.org/10.1177/1362168818799371 